\title{
Ontogenic Changes and Regulation of Renal Angiotensin II Type 1 Receptor Gene Expression during Fetal and Newborn Life ${ }^{1}$
}

\author{
JEAN E. ROBILLARD, BRIAN C. SCHUTTE, WILLIAM V. PAGE, JULIA A. \\ FEDDERSON, CRAIG C. PORTER, AND JEFFREY L. SEGAR
}

Department of Pediatrics and the Cardiovascular Center, University of Iowa, Iowa City, Iowa 52242

\section{ABSTRACT}

Factors regulating the expression of the angiotensin II subtype $1\left(\mathrm{AT}_{1}\right)$ receptor during fetal life have not been investigated previously. The present study was designed 1 ) to characterize the ontogeny of $\mathrm{AT}_{1}$ receptor gene expression in the kidney of fetal and newborn sheep and 2) to determine the influence of both glucocorticoids and renal nerves in modulating $\mathrm{AT}_{1}$ gene expression during fetal life and during the transition from fetal to newborn life. We first isolated and cloned a PCR product that has 98 and $94 \%$ homology with the cDNA encoding the bovine and pig $\mathrm{AT}_{1}$ receptors, respectively, and 99 and $98 \%$ homology with the corresponding deduced protein sequences. Probing with this cDNA, we demonstrated that renal $\mathrm{AT}_{1}$ mRNA expression did not change significantly during the last trimester of gestation in fetal sheep or immediately after birth but decreased significantly $10 \mathrm{~d}$ after birth. We also demonstrated that renal denervation in the fetus had no effect on renal $\mathrm{AT}_{1}$ gene expression in 24-h-old newborn lambs. On the other hand, we observed in 130-d twin fetuses that a continuous intraperitoneal infusion $(1 \mathrm{~mL} / \mathrm{h})$ of cortisol $(3$ $\mathrm{mg} / \mathrm{h}$ or $6.2 \mu \mathrm{mol} / \mathrm{h}$ ) for $48 \mathrm{~h}$ in one of the twins increased the fetal plasma cortisol concentration from $32.0 \pm 7.1$ to $1126 \pm 231 \mathrm{nmol} / \mathrm{L}$ and produced a significant decrease $(p$ $<0.005)$ in renal $\mathrm{AT}_{1}$ gene expression compared with the control twin receiving an intraperitoneal infusion of $0.9 \%$ $\mathrm{NaCl}$. In summary, this study demonstrates that renal $\mathrm{AT}_{1}$ gene expression is elevated during fetal life and decreases after birth. It is also shown that glucocorticoids, but not renal nerves, contribute to the regulation of renal $\mathrm{AT}_{1}$ gene expression during development. (Pediatr Res 36: 755-762, 1994)
Abbreviations
RAS, renin-angiotensin system
AII, angiotensin II
AT, angiotensin II subtype 1 receptor
$\mathbf{A T}_{2}$, angiotensin II subtype 2 receptor
PCR, polymerase chain reaction
RSNA, renal sympathetic nerve activity
PRA, plasma renin activity
rRNA, ribosomal RNA

It has become apparent that the physiologic role of the RAS changes during embryonic and fetal maturation (14). Early during development, the RAS exerts a major influence on cellular growth and organ differentiation (3-6). It is only later during fetal life that the RAS becomes an important modulator of blood pressure and fluid and electrolyte homeostasis $(2,7,8)$. Mechanisms regulating these changes are not well understood. Recent studies have suggested, however, that there are important developmental changes in the expression of the two

Received February 14, 1994; accepted June 10, 1994.

Correspondence: Jean E. Robillard, M.D., Professor, Department of Pediatrics, University of Iowa Hospitals and Clinics, 200 Hawkins Dr., Iowa City, IA 52242 .

Supported by the National Institutes of Health Grants HL-14388, DK-38302, and DK-43961. J.L.S. is supported by Clinical Investigator Development Award HL-02865.

${ }^{1}$ Presented in part at the American Society of Nephrology meetings, Boston, November 1993. distinct $\mathrm{AII}$ receptor subtypes $\left(\mathrm{AT}_{1}\right.$ and $\left.\mathrm{AT}_{2}\right)(3,9,10)$. The $\mathrm{AT}_{2}$ receptor subtype is expressed early during embryonic life in the rat $(11,12)$, predominates in the fetal mesenchyme (3), and shows a marked decrease in expression during fetal and postnatal maturation (3). On the other hand, the $\mathrm{AT}_{1}$ receptor subtype appears later during fetal development in the rat $(3,9,10)$ and seems to be localized mainly in areas related to blood pressure regulation and fluid homeostasis (3). Recent studies in rats have also shown that the $\mathrm{AT}_{1}$ receptor gene is expressed in the fetal kidney, liver, adrenal, and heart and that the expression of this gene is developmentally regulated (9, 10 ), in agreement with previous AII radioligand and in situ receptor-binding studies $(13,14)$; no similar studies have been done in the sheep fetus. $\mathrm{An}_{\mathrm{AT}_{3}}$ binding site has been characterized in a mouse cell line derived from neuroblastoma cells; the function of this binding site is presently unknown (15). 
Factors regulating the expression of $\mathrm{AT}_{1}$ receptor during fetal life have not been investigated previously. Several lines of evidence suggest, however, that both glucocorticoids and renal nerves may be important modulators of renal $\mathrm{AT}_{1}$ gene expression in the sheep fetus and during the transition from fetal to newborn life. Cortisol, which increases rapidly in fetal blood before delivery in sheep (16), is known to influence the maturation of various systems in the developing fetus (17) and has been shown to induce the expression of $\mathrm{AT}_{1}$ receptor gene in the adult (18). Recent studies in sheep have also demonstrated that renal nerves are major contributors to the increase in PRA and renal renin gene expression at birth (19).

The present study was therefore designed 1) to characterize the ontogeny of $\mathrm{AT}_{1}$ receptor gene expression in the kidney of fetal and newborn sheep and 2) to determine the influence of both the glucocorticoid, cortisol, and renal nerves in modulating renal $\mathrm{AT}_{1}$ gene expression during fetal life and during the transition from fetal to newborn life. To perform these studies, we also isolated and characterized a portion of the sheep $\mathrm{AT}_{1}$ receptor cDNA sequence.

\section{METHODS}

Animals and surgical preparation. Studies were performed in fetal sheep and newborn lambs of Dorset and Suffolk mixed breeding, obtained from a local source. The gestational ages of the fetuses were based on the induced ovulation technique as previously described (20).

Anesthesia and surgery of the ewe and fetus were performed as previously described $(19,21,22)$. Briefly, the ewe was fasted for $24 \mathrm{~h}$ before surgery and anesthetized using a mixture of halothane $(1 \%)$, oxygen $(33 \%)$, and nitrous oxide $(66 \%)$. Under sterile conditions, the uterus was opened over the fetal hindlimbs. Polyethylene catheters were placed into the fetal femoral arteries and veins bilaterally. In some cases, surgery was performed on twin fetuses and additional catheters were secured in the peritoneal cavity of each twin.

In other studies, bilateral flank incisions were made and renal nerves were severed and stripped bilaterally from along the aorta, renal arteries, and veins. This was followed by careful application of $10 \%$ phenol in absolute alcohol to the renal plexus and surrounding area, as previously described $(19,21)$. Sham-operated fetuses were submitted to the same surgical procedure except that the renal nerves were left intact and no phenol was applied. This technique of renal denervation decreases renal tissue norepinephrine content by $98 \%$ compared with intact kidneys $(21,23)$.

At the end of surgery, the fetal incisions were closed and the fetus was returned to the uterus. Uterine and maternal abdominal muscles and maternal skin were closed in separate layers. All catheters were exteriorized through a subcutaneous tunnel and placed in a cloth pouch on the ewe's flank. Ampicillin sodium (Wyeth Laboratories, Philadelphia, PA) was administered to the ewe intramuscularly before surgery $(2 \mathrm{~g})$ and infused into the amniotic cavity after surgery $(2 \mathrm{~g})$. Pregnant ewes were returned to individual pens and allowed free access to food and water. The animals were allowed $4-5 \mathrm{~d}$ to recover from the surgery.

All procedures were performed within the regulations of the Animal Welfare Act and the National Institutes of Health Guide for the Care and Use of Laboratory Animals and were approved by the University of Iowa Animal Care and Use Committee.

Experimental protocols. Animals were studied according to one of the following three experimental protocols. In a first series of studies, we determined the ontogeny of the kidney AII type 1 receptor $\left(\mathrm{AT}_{1}\right)$ during the fetal and neonatal periods in sheep. For these studies, pregnant ewes were anesthetized as previously described, and the uterus was exteriorized to gain access to the fetus. Samples of fetal kidney cortex were obtained at 90,115 , and $140 \mathrm{~d}$ of gestation (term $=145 \mathrm{~d}$ ); five different fetuses were studied at each age for a total of 15 fetuses. Similar procedures were performed in anesthetized newborn lambs at 1 and $10 \mathrm{~d}$ of age (five different newborn lambs were studied at each age). After being removed, the kidney cortex was snap frozen in liquid nitrogen and stored at $-70^{\circ} \mathrm{C}$. Animals used in this series of studies were not used in other experiments.

In a second series of studies designed to determine the role of renal nerves on $\mathrm{AT}_{1}$ gene expression at the time of birth, two groups of fetuses between 140 and $142 \mathrm{~d}$ gestation were prepared. One group of fetuses $(n=6)$ had renal denervation, whereas the other group $(n=5)$ had sham surgery. Anesthesia of the ewe and surgery of the fetus were performed as previously described $(19,21$, 23). After surgery, the ewes were kept in a restricted area, fed a standard diet, and allowed a 72-h recovery period. Before delivery, each fetus received a continuous i.v. infusion of $5 \%$ dextrose in water at a rate of 0.1 $\mathrm{mL} / \mathrm{min}$. After allowing a $60-\mathrm{min}$ equilibration period, fetal heart rate, arterial blood pressure, and amniotic pressure were monitored during a 30-min period. Arterial blood $(5 \mathrm{~mL})$ was collected at the end of the 30-min period for determination of arterial $\mathrm{pH}, \mathrm{PCO}_{2}$, and $\mathrm{PO}_{2}$.

After the fetal monitoring period, the pregnant ewe was brought back to the surgical suite, and the fetus was delivered by cesarean section performed under spinalepidural anesthesia using $10 \mathrm{~mL}$ of $1 \%$ lidocaine as previously described (24). Immediately after birth, the newborn lamb was dried and placed under an overhead infant radiant warmer to keep body temperature at $39^{\circ} \mathrm{C}$. The lamb was then returned to the laboratory, where it was placed in a harness and supported in a standing position. During the postnatal period, a continuous infusion of a solution of $10 \%$ dextrose, $0.2 \% \mathrm{NaCl}$, and $0.03 \mathrm{M} \mathrm{KCl}$ was administered i.v. at a rate of $100 \mathrm{~mL} / \mathrm{kg} / 24 \mathrm{~h}$. Arterial blood pressure and heart rate were monitored continuously during the first $24 \mathrm{~h}$ of life. Arterial blood $(5 \mathrm{~mL})$ 
was collected at $1,4,8$, and $24 \mathrm{~h}$ after birth. Newborn blood samples were replaced with blood collected from the fetal side of the placental circulation after the umbilical cord was cut at the time of the cesarean section, as previously described (24).

After $24 \mathrm{~h}$ of postnatal life, newborn lambs were anesthetized as described, and both kidneys were removed, snap frozen in liquid nitrogen, and stored at $-70^{\circ} \mathrm{C}$. Physiologic results obtained from animals used in these studies have been published previously (23).

In a third series of studies, we studied the effects of cortisol on the renal expression of $\mathrm{AT}_{1}$ gene in 10 pairs of chronically instrumented twin fetal sheep at $130 \mathrm{~d}$ gestation. After a 72-h recovery period from surgery, one of each set of twins was given a continuous intraperitoneal infusion of cortisol (molecular weight 484.52) for exactly $48 \mathrm{~h}$ at a rate of $3 \mathrm{mg} / \mathrm{h}(6.2 \mu \mathrm{mol} / \mathrm{h})(1 \mathrm{~mL} / \mathrm{h})$. The other twin served as the control and received an intraperitoneal infusion of $0.9 \% \mathrm{NaCl}(1 \mathrm{~mL} / \mathrm{h})$. The infusions were carried out with portable peristaltic infusion pumps (Cormed, Inc., Middleport, NY) secured on the back of the ewe in pockets of a specially designed jacket that allowed the animals to move freely during the infusion.

Fetal arterial blood pressure, heart rate, and amniotic pressure were monitored in each twin fetus for $30 \mathrm{~min}$ before and at the end of the 48-h intraperitoneal infusion of cortisol. Fetal arterial blood from each twin fetus was taken before and $48 \mathrm{~h}$ after starting the cortisol infusion for determination of arterial $\mathrm{pH}, \mathrm{PCO}_{2}, \mathrm{Po}_{2}$, and hematocrit, plasma cortisol and AII concentrations, and PRA.

At the end of the infusion period, the ewes were anesthetized as described, the uterine cavity was opened, and kidneys from both fetuses were removed, snap frozen in liquid nitrogen, and stored at $-70^{\circ} \mathrm{C}$.

Analytical procedures. Arterial blood for $\mathrm{pH}, \mathrm{PCO}_{2}$, and $\mathrm{PO}_{2}$ was collected anaerobically in heparinized glass syringes, and measurements were immediately determined with appropriate $\mathrm{pH}, \mathrm{PCO}_{2}$, and $\mathrm{Po}_{2}$ electrodes at $39^{\circ} \mathrm{C}$ using an IL-1303 pH blood gas analyzer (Laboratory Instruments, Schaumburg, IL). Hematocrit was determined in duplicate using a micrometer caliper. RIA, previously established in our laboratory, were used to measure plasma cortisol (22), plasma AII (25) concentrations, and PRA $(25,26)$.

Isolation of RNA. Total renal cortical cellular RNA was isolated using a modified isothiocyanate- $\mathrm{CsCl}$ method as previously described (27). RNA was quantified spectrophotometrically by absorbance at $260 \mathrm{~nm}$. RNA samples were stored as an ethanol precipitate at $-70^{\circ} \mathrm{C}$ until further analysis.

Isolation, characterization, and sequencing of $A T_{1}$ partial cDNA from sheep kidney. A partial $\mathrm{AT}_{1}$ cDNA clone was amplified by PCR from approximately $1 \mathrm{ng}$ of cDNA after reverse transcription. Reverse transcription was performed with $1 \mu \mathrm{g}$ of total RNA from sheep kidney using an avian myeloblastoma virus reverse transcriptase (Boehringer-Mannheim, Indianapolis, IN).
PCR was performed using two specific primers prepared by a model 391 DNA synthesizer (Applied Biosystems, Foster City, CA) and derived from the first and sixth transmembrane domains of the bovine $\mathrm{AT}_{1}$ receptor (28). The sequence of primer 1 (antisense) was 5'-AAA AGT GAA TAT CTG GTG GGG A-3', which was defined by bp 762-783 (28). The $\mathrm{AT}_{1}$ primer 2 (sense) encompassed bp 114-134 (28), and the sequence was 5'-CTT TGT GGT GGG GAT ATT TGG-3'. The conditions for PCR were $94^{\circ} \mathrm{C}$ for $1 \mathrm{~min}, 56^{\circ} \mathrm{C}$ for $1 \mathrm{~min}$, and $72^{\circ} \mathrm{C}$ for $1 \mathrm{~min}$ for 35 cycles followed by a final extension period of $72^{\circ} \mathrm{C}$ for $3 \mathrm{~min}$.

The 669-bp PCR product was gel purified (Qiaex, QIAGEN, Inc., Chatsworth, CA) and cloned into the plasmid vector pT7 Blue using the T-vector kit (Novagen, Madison, WI). The $\mathrm{AT}_{1}$ partial cDNA was recloned into the SpeI and KpnI restriction sites of pBluescriptII SK(Stratagene, La Jolla, CA), yielding the subclone $\mathrm{pAT}_{1}$. DNA sequencing was performed at the University of Iowa DNA Core Facility (Dave Moser, Director) on a model 373A automated DNA sequencer (Applied Biosystems) using vector and sequence-specific primers, Taq DNA polymerase, and fluorescent dye-labeled terminators. DNA and protein sequences were aligned using the program Bestfit from the Sequence Analysis Software Package of the Genetics Computer Group (29).

Preparation of $\boldsymbol{A T} \boldsymbol{T}_{1} \boldsymbol{R N A}$ probe. The plasmid $\mathrm{pAT}_{1}$ was treated with the restriction enzyme NdeI and then purified by phenol:chloroform:isoamyl alcohol $(25: 24: 1)$ and ethanol precipitation. The resultant linear plasmid was used to generate a labeled antisense RNA probe using $\mathrm{d}-\left[{ }^{32} \mathrm{P}\right] \mathrm{UTP}$ and T7 RNA polymerase (United States Biochemical, Cleveland, $\mathrm{OH}$ ).

Preparation of 18s rRNA probe. An 18s rRNA probe was also used to confirm equal loading and transfer of RNA. The 18s rRNA probe was prepared from an 18s cDNA clone corresponding to an 82-bp fragment of a highly conserved region of human 18s rRNA obtained from Ambion, Inc., Austin, TX.

Northern blot hybridization. Aliquots of $5 \mu \mathrm{g}$ of RNA were fractionated by formaldehyde-agarose gel electrophoresis (30). After electrophoresis, RNA was transferred to a $0.45-\mu \mathrm{m}$ Nytran filter (Schleicher and Schuell, Inc., Keene, NH). The filters were prehybridized for $1 \mathrm{~h}$ at $60^{\circ} \mathrm{C}$ in a solution of $50 \%$ deionized formamide, $5 \times$ SSPE (sodium chloride-sodium phosphate and EDTA), 5 $\times$ Denhardt's reagent, $0.5 \%$ SDS, and $200 \mu \mathrm{g} / \mathrm{mL}$ denaturated sheared salmon sperm DNA. Hybridization of filters was carried out with fresh hybridization buffer solution containing $2 \times 10^{6} \mathrm{cpm} \cdot \mathrm{mL}^{-1}$ of the radiolabeled $\mathrm{AT}_{1}$ probe. The hybridization reaction was carried at $60^{\circ} \mathrm{C}$ for $12-18 \mathrm{~h}$. Filters were then sequentially washed according to the manufacturer's specifications. This included three low-stringency washes $(1 \times \mathrm{SSPE}, 0.5 \%$ SDS $)$ at $68^{\circ} \mathrm{C}$ and a high-stringency wash $(0.1 \times$ SSPE, $0.5 \% \mathrm{SDS})$ at $65^{\circ} \mathrm{C}$. Hybridization signals were detected and quantitated using an AMBIS 4000 Radioanalytic Imaging System (AMBIS, Inc., San Diego, CA). The 
AMBIS 4000 simultaneously images and quantitates the radioisotopic signal generated by ${ }^{32} \mathrm{P}$ on the filters. The Ambion 4000 system uses a detector consisting of 3616 individual detector elements. These detector elements can detect both $\beta$ and $\gamma$ emissions over a $20 \times 20-\mathrm{cm}$ area. Counts were recorded in 532224 discrete detection points (data elements) from which a composite image was made and displayed on a color monitor so that regions of interest could be quantitated. Background counts above each lane were determined and subtracted from total counts generated in each region of interest to yield a net count value. In addition, the washed filters were exposed to Kodak XAR film at $-70^{\circ} \mathrm{C}$.

Southern blot hybridization. To test whether the sheep $\mathrm{AT}_{1}$ gene was encoded in a single locus, genomic sheep DNA was isolated from sheep blood. Ten $\mu \mathrm{g}$ of DNA were digested with each of the following restriction enzymes according to the manufacturer (New England Biolabs, Beverly, MA): BamHI, BglII, EcoRI, HindIII, and Pst $\mathrm{I}$. The digested DNA was separated on a $0.7 \%$ agarose gel and visualized on a UV transilluminator after staining with ethidium bromide. The DNA was transferred to a nylon membrane (Hybond $\mathrm{N}^{+}$, Amersham Co., Arlington Heights, IL) by capillary action and immobilized on the membrane by UV cross-linking (Stratalinker, Stratagene). The partial cDNA probe of the sheep $\mathrm{AT}_{1}$ gene was gel purified and random primed with digoxigenin. Labeling, hybridization, and detection were performed as suggested by the manufacturer (Boehringer-Mannheim).

Data analysis. For quantitation of mRNA abundance, all samples were analyzed together on a single Northern blot hybridization to control for day-to-day variations in hybridization efficiency. Northern blots were done in triplicate. Abundance of $\mathrm{AT}_{1}$ mRNA was expressed as total net radioactive counts after subtracting background counts for each sample.

Comparisons among the different groups of animals were performed using one-way analysis of variance. When the analysis of variance indicated significant differences among groups, as calculated by the $F$ statistic, the Duncan multiple comparison procedure was performed to determine significant differences between groups (31). Paired and unpaired $t$ tests were also used to compare means between two groups. Statistical significance was defined as $p<0.05$, and the results are presented as mean \pm SEM.

\section{RESULTS}

Isolation, characterization, and sequencing of $A T_{1}$ receptor partial cDNA from sheep kidney. The sheep $\mathrm{AT}_{1}$ receptor partial cDNA sequence from nucleotide 114 to 783 is presented in Figure 1 and compared with corresponding $\mathrm{AT}_{1} \mathrm{cDNA}$ sequences from other species. This sequence is $99 \%$ homologous with bovine $\mathrm{AT}_{1}(28), 94 \%$ with pig $\mathrm{AT}_{1}(32)$, 92\% with human $\mathrm{AT}_{1}(33,34), 87 \%$ with rat $\mathrm{AT}_{1 \mathrm{~A}}(35-37)$, and $86 \%$ with rat $\operatorname{AT}_{1 \mathrm{~B}}(35,38)$. The

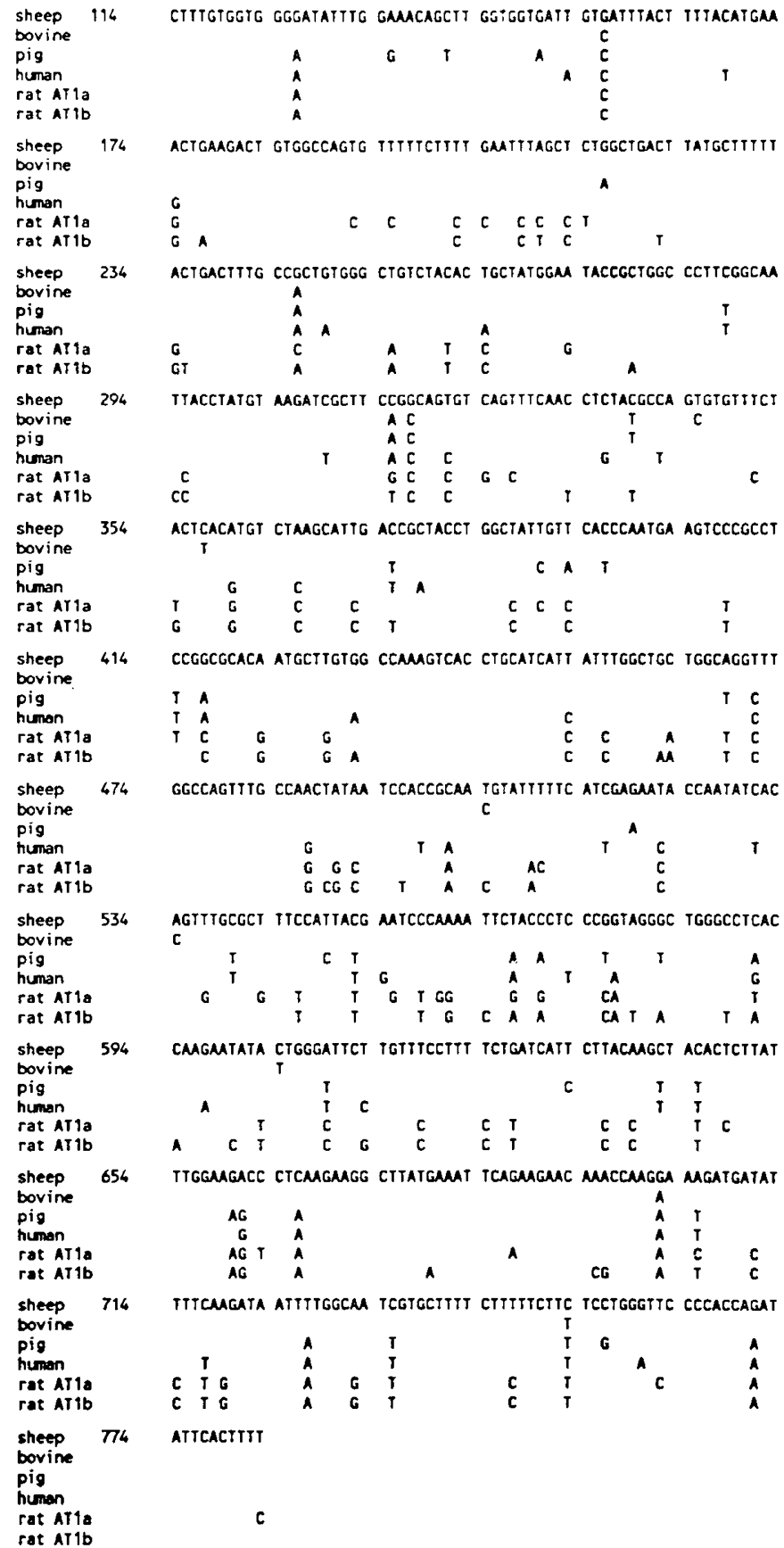

Figure 1. Sheep $\mathrm{AT}_{1}$ partial cDNA sequence from nucleotide 114 to 783 and interspecies comparisons. The percent homology between $\mathrm{AT}_{1}$ partial cDNA sequence from sheep kidney and corresponding $\mathrm{AT}_{1}$ cDNA sequences from other species is $99 \%$ with bovine $\mathrm{AT}_{1}(28), 94 \%$ with pig $\mathrm{AT}_{1}(32), 92 \%$ with human $\mathrm{AT}_{1}(33,34), 87 \%$ with rat $\mathrm{AT}_{1 \mathrm{~A}}$ (35-37), and $86 \%$ with rat $\mathrm{AT}_{1 \mathrm{~B}}(35,38)$.

deduced amino acid sequence and the interspecies comparison of sheep kidney $\mathrm{AT}_{1}$ receptor obtained from the $\mathrm{AT}_{1}$ partial nucleotide sequence are presented in Figure 2.

The degree of sequence homologies between the sheep $\mathrm{AT}_{1}$ partial cDNA and the other species (Fig. 1) ranges from 86 to $99 \%$ at the DNA level and from 93 to $99 \%$ at the amino acid level (Fig. 2), indicating that primers derived from the bovine $\mathrm{AT}_{1}$ sequence faithfully amplified the sheep $\mathrm{AT}_{1}$ homologue. 


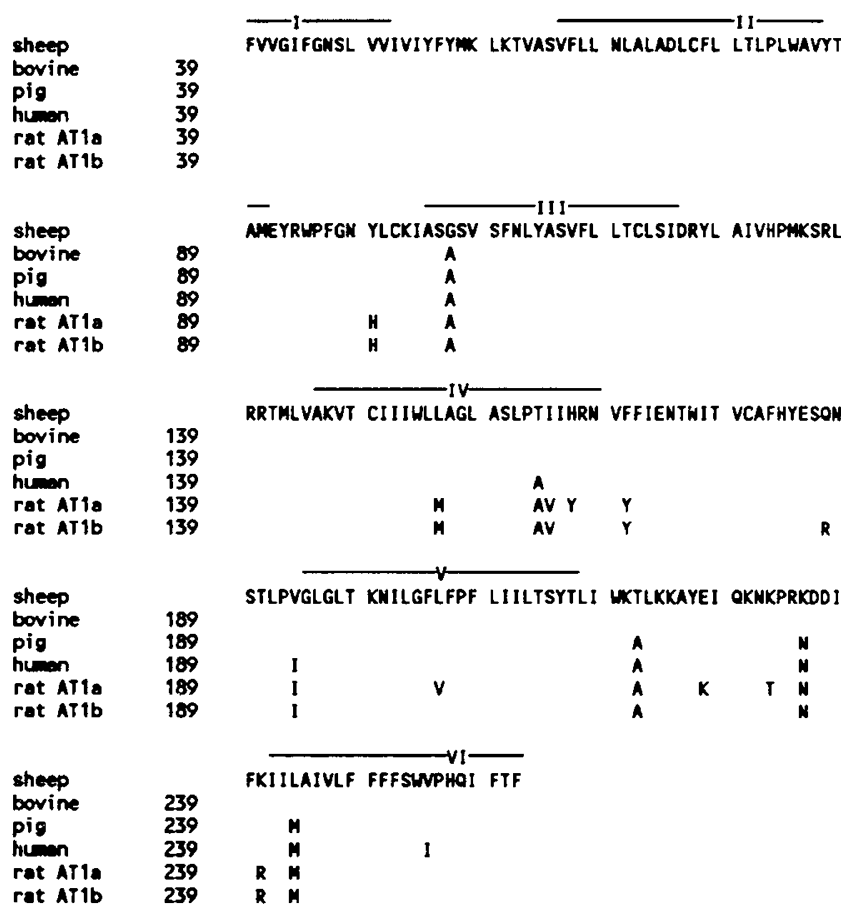

Figure 2. Sheep $\mathrm{AT}_{1}$ partial amino acid sequence and interspecies comparisons. The percent homology between sheep kidney $\mathrm{AT}_{1}$ partia amino acid sequence and corresponding $\mathrm{AT}_{1}$ amino acid sequences from other species is $99 \%$ with bovine $\mathrm{AT}_{1}(28), 98 \%$ with pig $\mathrm{AT}_{1}$ (32), $96 \%$ with human $\mathrm{AT}_{1}(34,40), 94 \%$ with rat $\mathrm{AT}_{1 \mathrm{~B}}(35)$, and $93 \%$ with rat $\mathrm{AT}_{1 \mathrm{~A}}$ (38). This partial amino acid sequence includes the putative transmembrane domains II to $\mathrm{V}$ and portions of I and VI; transmembrane domain VII is not included in this partial sequence. The transmembrane domains included in this partial sequence are indicated above the amino acid sequence.

In addition, Southern analysis was performed on genomic sheep DNA with the 669-bp $\mathrm{AT}_{1}$ partial cDNA as a probe. Only a single band was observed using several different enzymes, suggesting that the sheep $\mathrm{AT}_{1}$ gene is encoded at a single locus (data not shown).

Ontogeny of renal $A T_{1}$ mRNA expression in fetal and newborn sheep. Kidney total RNA from fetal and newborn sheep resolved by Northern blot and hybridized with a sheep-specific $\mathrm{AT}_{1} \mathrm{cDNA}$ showed one transcript corresponding to the cloned $\mathrm{AT}_{1}$ cDNA (Fig. 3). Renal $\mathrm{AT}_{1}$ gene expression does not change significantly during the last trimester of gestation in fetal sheep (Fig. 3). Twentyfour $\mathrm{h}$ after birth, $\mathrm{AT}_{1}$ gene expression tended to increase further, but the increase was not found to be significant. A significant decrease in renal $\mathrm{AT}_{1}$ gene expression was observed $10 \mathrm{~d}$ after birth.

Effect of fetal renal denervation on renal $A T_{1}$ mRNA expression at birth. We postulated that fetal renal denervation, which blunts the increase in PRA at birth (19), should produce an up-regulation of $\mathrm{AT}_{1}$ gene expression. Contrary to our hypothesis, however, we found that fetal renal denervation produced no significant changes in renal $\mathrm{AT}_{1}$ mRNA expression of 24-h-old newborn lambs $(n=6)$ compared with sham-operated control animals $(n$ $=5)$ (Fig. 4). Renal $\mathrm{AT}_{1}$ mRNA expression expressed as ${ }^{32} \mathrm{P}$ net counts was $19375 \pm 2625$ in denervated animals

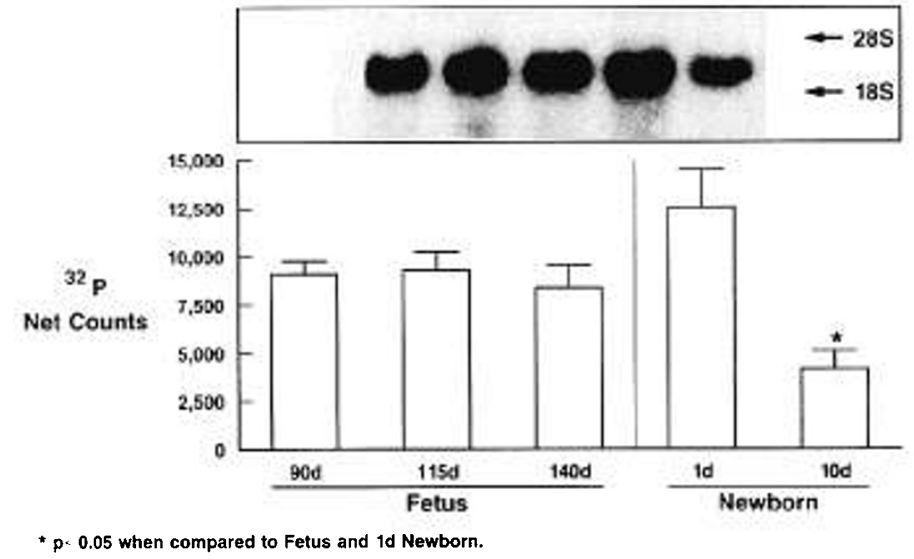

Figure 3. Upper panel, Representative autoradiogram of a Northern blot of total renal cortical RNA hybridized with a sheep AT, RNA probe labeled with ${ }^{32} \mathrm{P}$. Total RNA was extracted from fetal and newborn sheep, one from each of the five groups. From left to right are results from 90,115 , and $140 \mathrm{~d}$ of gestation fetal sheep and from 1- and 10-d-old newborn lambs. Lower panel, Abundance of renal $\mathrm{AT}_{1}$ mRNA is expressed as total net counts of ${ }^{32} \mathrm{P}$ in the five age groups; $n=5$ in each group. Values are means \pm SEM.

and $22956 \pm 2058$ in control animals. No significant differences were observed in renal 18s rRNA expression between intact and denervated kidneys, indicating similar RNA loading: 18s rRNA expressed as ${ }^{32} \mathrm{P}$ net counts was $2435 \pm 157$ in intact kidneys and $2676 \pm 65$ in denervated kidneys.

Effects of cortisol infusion on kidney $A T_{1}$ mRNA expression in third-trimester fetal sheep. This series of studies was designed to test the hypothesis that glucocorticoids play an important role in regulating kidney $\mathrm{AT}_{1}$ mRNA expression during development. To test this hypothesis, 10 pairs of chronically instrumented fetal sheep were studied at $130 \mathrm{~d}$ of gestation. One of each set of twins received a continuous intraperitoneal infusion $(1 \mathrm{~mL} / \mathrm{h})$ of cortisol for $48 \mathrm{~h}(3 \mathrm{mg} / \mathrm{h}$ or $6.2 \mu \mathrm{mol} / \mathrm{h})$, and the other

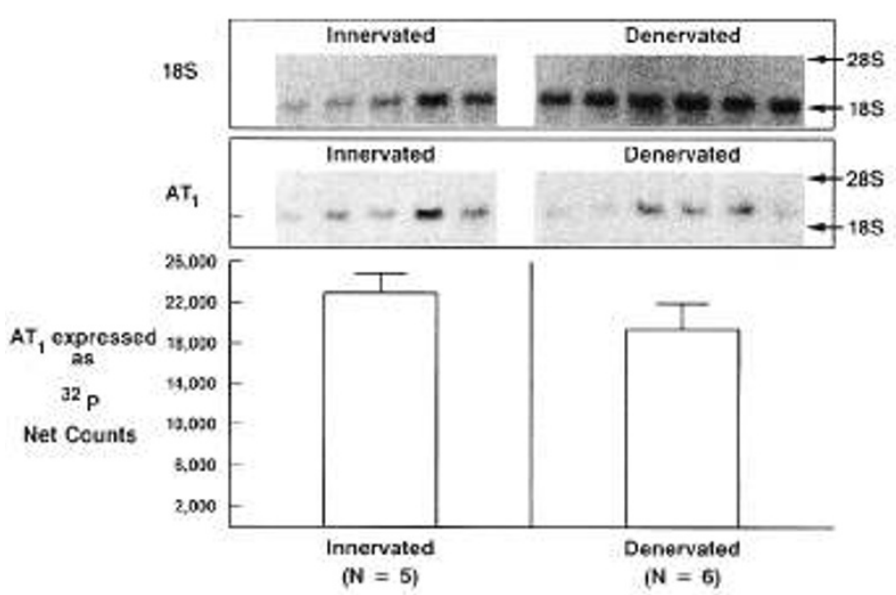

Figure 4. Upper panel, Autoradiogram of a Northern blot of total renal cortical RNA hybridized with a human 18 s rRNA probe and with a sheep $\mathrm{AT}_{1}$ RNA probe labeled with ${ }^{32} \mathrm{P}$. Total renal cortical RNA was extracted from denervated $(n=6)$ and intact $(n=5)$ kidneys of newborn lambs at $24 \mathrm{~h}$ of age. Lower panel, Abundance of renal $\mathrm{AT}_{1}$ mRNA is expressed as total net counts of ${ }^{32} \mathrm{P}$. Values are means \pm SEM. 
Table 1. Arterial blood values, mean arterial blood pressure, and heart rate in both control and cortisol-treated fetal sheep*

\begin{tabular}{|c|c|c|c|c|}
\hline & \multicolumn{2}{|c|}{ Control } & \multicolumn{2}{|c|}{ Cortisol-treated } \\
\hline & Pre & $48 \mathrm{~h}$ & Pre & $48 \mathrm{~h}$ \\
\hline $\mathrm{pH}$ & $7.34 \pm 0.01$ & $7.31 \pm 0.01 \dagger \ddagger$ & $7.35 \pm 0.01$ & $7.35 \pm 0.01$ \\
\hline $\mathrm{PCO}_{2}(\mathrm{~mm} \mathrm{Hg})$ & $51.7 \pm 1.3$ & $49.8 \pm 1.2$ & $50.2 \pm 0.9$ & $48.9 \pm 1.6$ \\
\hline $\mathrm{Po}_{2}(\mathrm{~mm} \mathrm{Hg})$ & $20.6 \pm 1.2$ & $17.4 \pm 0.8$ & $19.4 \pm 1.8$ & $18.2 \pm 1.4$ \\
\hline Cortisol $(\mathrm{nmol} / \mathrm{L})$ & $22.7 \pm 3.6$ & $45.8 \pm 8.2 \ddagger$ & $32.0 \pm 7.1$ & $1126 \pm 231 \dagger$ \\
\hline PRA (ng AI $\cdot \mathrm{mL}^{-1} \cdot \mathrm{h}^{-1}$ ) & $3.38 \pm 0.67$ & $5.38 \pm 1.39 \ddagger$ & $5.47 \pm 1.26$ & $1.21 \pm 0.32 \dagger$ \\
\hline AII $(\mathrm{pg} / \mathrm{mL})$ & $35.6 \pm 6.0$ & $54.1 \pm 5.9$ & $46.5 \pm 6.4$ & $68.4 \pm 25.4$ \\
\hline Het $(\%)$ & $35 \pm 3$ & $34 \pm 3$ & $36 \pm 3$ & $35 \pm 2$ \\
\hline HR (bpm) & $160 \pm 3$ & $157 \pm 13$ & $154 \pm 13$ & $174 \pm 17$ \\
\hline $\mathrm{MABP}(\mathrm{mm} \mathrm{Hg})$ & $49 \pm 1$ & $45 \pm 5$ & $49 \pm 2$ & $51 \pm 4$ \\
\hline
\end{tabular}

${ }^{*}$ Pre, before starting intraperitoneal infusion $(1 \mathrm{~mL} / \mathrm{h})$ of either $0.9 \% \mathrm{NaCl}$ or cortisol $(3 \mathrm{mg} / \mathrm{h}) ; 48 \mathrm{~h}, 48 \mathrm{~h}$ after starting intraperitoneal infusion of either $0.9 \% \mathrm{NaCl}$ or cortisol; Hct, hematocrit; HR, heart rate; MABP, mean arterial blood pressure. Conversion factor for SI units: $1 \mathrm{~mm} \mathrm{Hg}$ $=133.3 \mathrm{~Pa}, 1 \mathrm{~mol}$ of $\mathrm{AII}=1046 \mathrm{~g}, 1 \mathrm{~mol}$ of $\mathrm{AI}=1296 \mathrm{~g}$. Values are means $\pm \mathrm{SEM}$.

$\dagger p<0.05$ compared with Pre values.

$\ddagger p<0.05$ compared with corresponding 48 -h experimental (cortisol-treated) values.

twin (control) received the same volume $(1 \mathrm{~mL} / \mathrm{h})$ of $0.9 \%$ $\mathrm{NaCl}$ intraperitoneally. Plasma cortisol concentrations were similar $(p=0.268)$ before cortisol infusion in both treated $(32.0 \pm 7.1 \mathrm{nmol} / \mathrm{L})$ and control $(22.7 \pm 3.6$ $\mathrm{nmol} / \mathrm{L})$ fetuses. Treated fetuses had significantly $(p<$ $0.001)$ higher plasma cortisol levels $(1126 \pm 231 \mathrm{nmol} / \mathrm{L})$ after $48 \mathrm{~h}$ of intraperitoneal cortisol infusion compared with control fetuses $(45.8 \pm 8.2 \mathrm{nmol} / \mathrm{L})$.

As shown in Table 1, plasma cortisol infusion had no significant effects on fetal arterial $\mathrm{pH}, \mathrm{PO}_{2}$, and $\mathrm{PCO}_{2}$. A small but significant decrease in arterial $\mathrm{pH}$ was seen in control fetuses receiving $0.9 \% \mathrm{NaCl}$. PRA decreased significantly from $5.47 \pm 1.26$ to $1.21 \pm 0.32 \mathrm{ng}$ AI $\cdot \mathrm{mL}^{-1} \cdot \mathrm{h}^{-1}$ in cortisol-treated fetuses (Table 1). No significant changes in plasma AII levels were observed in either control or cortisol-treated fetuses. Cortisol infusion had no significant effects on fetal heart rate or mean arterial blood pressure.

Northern blot hybridization demonstrated a significant $(p<0.005)$ decrease in renal $\mathrm{AT}_{1}$ mRNA levels in treated fetuses (Fig. 5). The ${ }^{32} \mathrm{P}$ net counts were significantly higher $(p<0.005)$ in control fetuses $(1072 \pm 72$ net counts) than in treated fetuses $(679 \pm 33$ net counts) (Fig. $5)$. Hybridization to an 18s rRNA probe showed no significant differences between control $(395 \pm 20$ net counts) and treated fetuses (409 \pm 21 net counts), indicating similar RNA loading.

\section{DISCUSSION}

The present study demonstrates that renal $\mathrm{AT}_{1}$ receptor mRNA expression does not change during the last trimester of gestation in fetal sheep and during the transition from fetal to newborn life but decreases to lower levels 1 wk after birth. Furthermore, this study shows that the expression of renal $\mathrm{AT}_{1}$ receptor mRNA at birth is independent of changes in RSNA. Finally, we have observed that an increase in fetal plasma cortisol concentration to levels similar to the ones observed at the time of parturition (41) produces a decrease in renal $\mathrm{AT}_{1}$ mRNA expression.
Previous studies in rats (9) have shown that renal $\mathrm{AT}_{1}$ gene expression undergoes marked alterations during early development; renal $\mathrm{AT}_{1}$ mRNA expression is higher during the fetal and newborn periods than during adult life in rats (9). The present results confirm these findings and demonstrate that there is no change in renal $\mathrm{AT}_{1}$ mRNA expression during the last trimester of gestation in fetal sheep. The developmental changes in the intrarenal distribution of $\mathrm{AT}_{1}$ mRNA were not investigated in the present study. Previous studies in rats using in situ hybridization $(9,10)$ have shown, however, that specific hybridization signals for $\mathrm{AT}_{1}$ receptor, including $\mathrm{S}$-shaped body, are present in glomeruli at different maturation stages and localized to mesenchymal cells that contribute to the formation of the glomerular mesangium. $\mathrm{AT}_{1}$ mRNA expression has also been observed in arteries

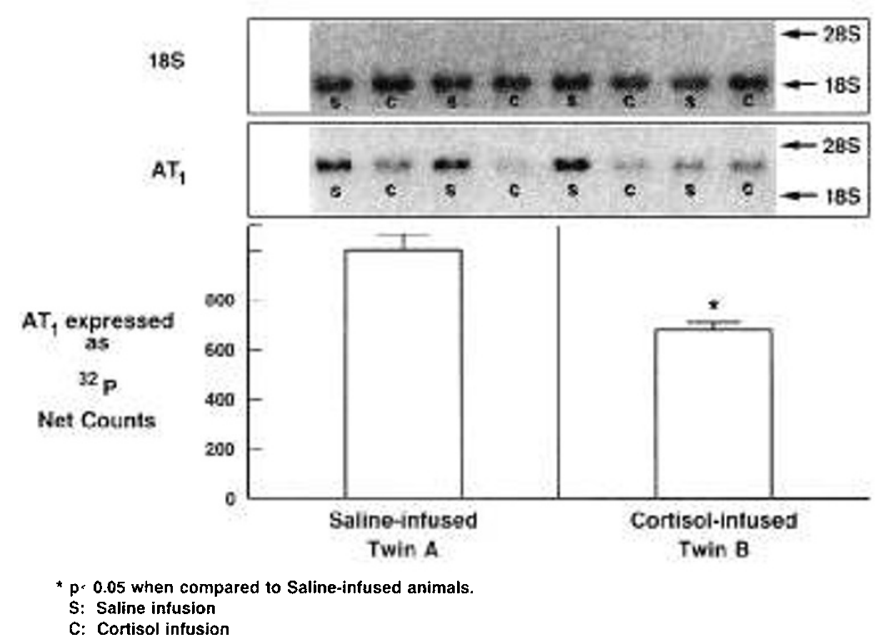

Figure 5. Upper panel, Representative autoradiograms of Northern blots of total renal cortical RNA hybridized with a human 18s rRNA probe and with a sheep $\mathrm{AT}_{1}$ RNA probe labeled with ${ }^{32} \mathrm{P}$. Total renal cortical RNA was extracted from saline-infused $(0.9 \% \mathrm{NaCl})(S)$ and cortisol-infused $(C)$ twin fetal sheep at $130 \mathrm{~d}$ gestation. Each pair of saline-infused and cortisol-infused blots represents twin fetuses studied simultaneously. Lower panel, Abundance of renal $\mathrm{AT}_{1}$ mRNA is expressed as total net counts of ${ }^{32} \mathrm{P}$. Ten pairs of twin fetuses were studied. Values are means \pm SEM. 
of the inner cortex and in the medulla along tubular epithelial structures $(9,10)$. To determine some of the mechanisms regulating the expression of renal $\mathrm{AT}_{1}$ receptors during development in sheep, we first investigated the role of renal nerves. Because RSNA increases rapidly at birth (42) and renal nerves contribute to the increase in PRA and renal renin mRNA expression at birth $(19,23)$, we postulated that renal nerves could also modulate renal $\mathrm{AT}_{1}$ gene expression. More specifically, we speculated that the increase in RSNA and RAS activity at birth could activate a negative-feedback loop that may restrain the increase in renal $\mathrm{AT}_{1}$ gene expression. Based on this hypothesis, one would predict that renal denervation should up-regulate $\mathrm{AT}_{1}$ receptors and induce an increase in renal $\mathrm{AT}_{1}$ gene expression. Contrary to our hypothesis, however, we observed no changes in renal $\mathrm{AT}_{1}$ mRNA expression at birth after renal denervation. These results suggest that, contrary to the influence of renal nerves on PRA and kidney renin gene expression at birth (19), an increase in RSNA during the transition from fetal to newborn life does not affect renal $\mathrm{AT}_{1}$ gene expression. One may also speculate that the intracellular signal mediating AII negative feedback on $\mathrm{AT}_{1}$ gene expression is not fully developed at birth or that AII is not an important modulator of $\mathrm{AT}_{1}$ mRNA expression. Alternatively, AII feedback could be reset at a higher level early during development, as previously suggested (9).

In another series of studies, we investigated the effect of an increase in fetal plasma cortisol concentration on renal $\mathrm{AT}_{1}$ gene expression. We postulated that cortisol, which is known to increase rapidly before delivery (16) and to influence the maturation of various organ systems during fetal life (17), may regulate the increase in renal $\mathrm{AT}_{1}$ mRNA expression at birth. In support of this hypothesis, in vitro studies of vascular smooth muscle cells from adult rats have shown that dexamethasone increases the vascular sensitivity to AII by potentiating inositol triphosphate (43) and induces the expression of $\mathrm{AT}_{1}$ gene (43). Contrary to these results in adult rats (43), the present study demonstrates that an increase in fetal sheep plasma cortisol concentration to levels usually observed at birth (16) decreases renal $\mathrm{AT}_{1}$ mRNA expression. Reasons for the differences between studies in adult rats (43) and the present results in fetal sheep were not investigated. Species differences and differential regulatory responses to glucocorticoid between adult and fetal animals could explain some of the differences observed. One may also speculate that the regulation of $\mathrm{AT}_{1}$ gene expression by glucocorticoid is tissue and cell specific. Indeed, glucocorticoid has been shown to downregulate both $\mathrm{AT}_{1}$ and $\mathrm{AT}_{2}$ receptors in pancreatic acinar cells (44) and to produce down-regulation of glomerular AII receptor in rats (45). Another possibility is that the decreased expression of renal $\mathrm{AT}_{1}$ gene as a function of cortisol concentration is indirect and depends on factors interacting with specific DNA sequences on the glucocorticoid regulatory elements, as previously suggested
$(22,46)$. One may also speculate that developmental changes in the physiochemical nature of glucocorticoid receptors $(47,48)$ affect the hormonal responsiveness of certain genes during fetal life. Finally, it is possible that cortisol, which has both glucocorticoid and mineralocorticoid activities, stimulates different receptors than dexamethasone, which is a synthetic glucocorticoid without mineralocorticoid activity. Additional studies are needed to clarify these issues.

The present study also demonstrates that chronic infusion of cortisol decreases fetal PRA, as previously observed $(49,50)$, without producing significant changes in plasma AII levels. This absence of change in plasma AII levels in the face of a decrease in PRA is somewhat intriguing. One may suggest that cortisol increases the production of angiotensinogen (renin substrate) to prevent changes in plasma AII levels in face of a decrease in renin production. Previous studies in sheep, however, have shown that fetal cortisol infusion does not produce changes in circulating angiotensinogen (50) and is, in fact, associated with a decrease in liver angiotensinogen mRNA levels (22), in contrast to previous findings in adults $(51,52)$. An alternative hypothesis would be that cortisol infusion in fetal sheep increases converting enzyme activity and consequently the rate of conversion of angiotensin I to AII, as previously suggested (53). Finally, one may suggest that cortisol alters both plasma and tissue angiotensinases involved in the metabolism of AII. The present study, however, was not designed to test these hypotheses.

In summary, renal $\mathrm{AT}_{1}$ gene expression does not change during the last trimester of gestation in sheep, but decreases postnatally. Changes in RSNA and in the activity of the RAS at birth do not seem to be important regulators of renal $\mathrm{AT}_{1}$ gene expression. Contrary to previous findings in adult rats (43), glucocorticoids decrease renal $\mathrm{AT}_{1}$ gene expression during fetal life in sheep.

Acknowledgment. The authors thank Ruth Hurlburt for her assistance in the preparation of this manuscript.

\section{REFERENCES}

1. Gomez RA 1990 Molecular biology of components of the renin-angiotensin system during development. Pediatr Nephrol 4:421-423

2. Robillard JE, Nakamura KT 1988 Neurohormonal regulation of renal function during development. Am J Physiol 254:F771-F779

3. Grady EF, Sechi LA, Griffin CA, Schambelan M, Kalinyak JE 1991 Expression of AT2 receptors in the developing rat fetus. J Clin Invest 88:921-933

4. Ray PE, Aguilera G, Kopp JB, Horikoshi S, Klotman PE 1991 Angiotensin II receptor-mediated proliferation of cultured human fetal mesangial cells. Kidney Int 40:764-771

5. Fogo A, Yoshida Y, Yared A, Ichikawa I 1990 Importance of angiogenic action of angiotensin II in the glomerular growth of maturing kidneys. Kidney Int 38:1068-1074

6. Pryde PG, Sedman AB, Nugent CE, Barr Jr M 1993 Angiotensin-converting enzyme inhibitor fetopathy. J Am Soc Nephrol 3:1575-1582

7. Robillard JE, Smith FG, Smith Jr FG 1992 Developmental aspects of renal function during fetal life. In: Edelmann CM, Bernstein J, Meadow SR, Spitzer A, Travis LB (eds) Pediatric Kidney Disease, Vol I. Little, Brown and Company, Boston, pp 3-18

8. Robillard JE, Weismann DN, Gomez RA, Ayres NA, Lawton WJ, VanOrden DE 1983 Renal and adrenal responses to converting-enzyme inhibition in fetal and newborn life. Am J Physiol 244:R249-R256 
9. Tufro-McReddie A, Harrison JK, Everett AD, Gomez RA 1993 Ontogeny of type 1 angiotensin II receptor gene expression in the rat. J Clin Invest 91:530-537

10. Shanmugam S, Monnot C, Corvol P, Gase J-M 1994 Distribution of type 1 angiotensin II receptor subtype messenger RNAs in the rat fetus. Hypertension 23:137-141

11. Tsutsumi K, Viswanathan M, Stromberg C, Saavedra JM 1991 Type 1 and type 2 angiotensin II receptors in fetal rat brain. Eur J Pharmacol 198:89-92

12. Tsutsumi K, Saavedra JM 1992 Heterogeneity of angiotensin II AT2 receptors in the rat brain. Mol Pharmacol 41:290-297

13. Zemel S, Millan MA, Ferillan P, Aguilera G 1990 Characterization and distribution of angiotensin II receptors in the primate fetus. J Clin Endocrinol Metab 71:1003-1007

14. Grone H-J, Simon M, Fuchs E 1992 Autoradiographic characterization of angiotensin receptor subtypes in fetal and adult human kidney. Am J Physiol 262:F326-F331

15. Chaki S, Inagami $T 1992$ Identification and characterization of a new binding site for angiotensin II in mouse neuroblastoma Neuro-2A cells. Biochem Biophys Res Commun 182:388-394

16. Nathanielsz PW 1976 Adrenocorticotropin. In: Nathanielsz PW (ed) Fetal Endocrinology: An Experimental Approach. North-Holland Publishing Company, Amsterdam, pp 125-150

17. Ballard PL 1979 Glucocorticoids and differentiation. In: Baxter JD, Rousseau GG (eds) Monograph on Endocrinology, Vol 12. Springer-Verlag, Berlin, pp 493-515

18. Sato A, Suzuki H, Murakami M, Nakazato Y, Iwaita Y, Saruta T 1994 Glucocorticoid increases angiotensin II type 1 receptor and its gene expression. Hypertension 23:25-30

19. Page WV, Perlman S, Smith FG, Segar JL, Robillard JE 1992 Renal nerves modulate kidney renin gene expression during the transition from fetal to newborn life. Am J Physiol 262:R459-R463

20. Jennings JJ, Crowley JP 1972 The influence of mating management on fertility in ewes following progesterone-PMS treatment. Vet Rec 90:495-498

21. Robillard JE, Nakamura KT, DiBona GF 1986 Effects of renal denervation on renal responses to hypoxemia in fetal lambs. Am J Physiol 250:F294-F301

22. Olson AL, Robillard JE, Kisker CT, Smith BA, Perlman S 1991 Negative regulation of angiotensinogen gene expression by glucocorticoids in fetal sheep liver. Pediatr Res 30:256-260

23. Smith FG, Smith BA, Guillery EN, Robillard JE 1991 Role of renal sympathetic nerves in lambs during the transition from fetal to newborn life. $J$ Clin Invest 88:1988-1994

24. Nakamura KT, Matherne GP, McWeeny OJ, Smith BA, Robillard JE 1987 Renal hemodynamics and functional changes during the transition from fetal to newborn life in sheep. Pediatr Res 21:229 -234

25. Robillard JE, Gomez RA, VanOrden D, Smith Jr FG 1982 Comparison of the adrenal and renal responses to angiotensin II in fetal lambs and adult sheep. Circ Res 50:140-147

26. Haber E, Koerner T, Page LB, Kliman B, Purnobe A 1969 Application of a radioimmunoassay for angiotensin $I$ to the physiologic measurements of plasma renin activity in normal human subjects. J Clin Endocrinol Metab 29:1349-1355

27. Olson AL, Perlman S, Robillard JE 1990 Developmental regulation of angiotensinogen gene expression in sheep. Pediatr Res 28:183-185

28. Sasaki K, Yamano Y, Bardhan S, Iwai N, Murray JJ, Hasegawa M, Matsuda Y, Inagami T 1991 Cloning and expression of a complementary DNA encoding a bovine adrenal angiotensin II type-1 receptor. Nature 351:230-233

29. Devereux J, Haeberli P, Smithies O 1984 A comprehensive set of sequence analysis programs for the VAX. Nucleic Acids Res 12:387-395

30. Lehrach H, Diamond D, Wozney JM, Boedtker H 1977 RNA molecular weight determinations by gel electrophoresis under denaturing conditions, a critical re-examination. Biochemistry 16:4743-4751
31. Zar JH 1984 Biostatistical Analysis. Prentice-Hall, Englewood Cliffs, NJ, pp $1-718$

32. Itazaki K, Shigeri Y, Fujimoto M 1993 Molecular cloning and characterization of the angiotensin receptor subtype in porcine aortic smooth muscle. Eur J Pharmacol 245:147-156

33. Bergsma DJ, Ellis C, Kumar C, Nuthulaganti P, Kersten H, Elshourbagy N, Griffin E, Stadel JM, Aiyar N 1992 Cloning and characterization of a human angiotensin II type 1 receptor. Biochem Biophys Res Commun 183:989-995

34. Furuta H, Guo D-F, Inagami T 1992 Molecular cloning and sequencing of the gene encoding human angiotensin II type receptor. Biochem Biophys Res Commun 183:8-13

35. Iwai N, Inagami $\mathrm{T} 1992$ Identification of two subtypes in the rat type I angiotensin II receptor. FEBS Lett 298:257-260

36. Iwai N, Yamano Y, Chaki S, Konishi F, Bardhan S, Tibbetts C, Sasaki K, Hasegawa M, Matsuda Y, Inagami T 1991 Rat angiotensin II receptor: cDNA sequence and regulation of the gene expression. Biochem Biophys Res Commun 177:299-304

37. Murphy TJ, Alexander RW, Griendling KK, Runge MS, Bernstein KE 1991 Isolation of a cDNA encoding the vascular type- 1 angiotensin II receptor. Nature 351:233-236

38. Kakar SS, Sellers JC, Devor DC, Musgrove LC, Neill JD 1992 Angiotensin II type-1 receptor subtype cDNAs: differential tissue expression and hormonal regulation. Biochem Biophys Res Commun 183:1090-1096

39. Deleted in proof

40. Curnow KM, Pascoe L, White PC 1992 Genetic analysis of the human type-1 angiotensin II receptor. Mol Endocrinol 6:1113-1118

41. Alexander DP, Britton HG, Nixon DA, Ratcliffe JG, Redstone D 1973 Corticotrophin and cortisol concentrations in the plasma of the chronically catheterised sheep fetus. Biol Neonate 23:184-192

42. Segar JL, Mazursky JE, Robillard JE 1994 Changes in ovine renal sympathetic nerve activity and baroreflex function at birth. Am J Physiol (in press)

43. Sato A, Suzuki H, Iwaita Y, Nakazato Y, Kato H, Surata T 1992 Potentiation of inositol triphosphate production by dexamethasone. Hypertension 19:109-115

44. Chappell MC, Jacobsen DW, Tallant EA 1992 Glucocorticoids downregulate both $\mathrm{AT}_{1}$ and $\mathrm{AT}_{2}$ angiotensin II receptors in pancreatic acinar cells. Hyper tension 20:435(abstr)

45. Douglas JG 1987 Corticosteroids decrease glomerular angiotensin receptors. Am J Physiol 252:F453-F457

46. Diamond MI, Miner JN, Yoshinaga SK, Yamamoto KR 1990 Transcription factor interactions: selectors of positive or negative regulation from a single DNA element. Science 249:1266-1272

47. Kalimi M, Gupta S 1982 Physicochemical characterization of rat liver glucocorticoid receptor during development. J Biol Chem 257:13324-13328

48. Feldman D 1974 Ontogeny of rat hepatic glucocorticoid receptors. Endocrinology 95:1219-1227

49. Wood CE, Keil LC, Rudolph AM 1984 Physiological inhibition of ovine fetal plasma renin activity by cortisol. Endocrinology 115:1792-1796

50. Wood CE 1986 Sensitivity of cortisol-induced inhibition of ACTH and renin in fetal sheep. Am J Physiol 250:R795-R802

51. Kunapuli SP, Benedict CR, Kumar A 1987 Tissue specific hormonal regulation of the rat angiotensinogen gene expression. Arch Biochem Biophys 254:642-646

52. Kalinyak JE, Perlman AJ 1987 Tissue-specific regulation of angiotensinogen mRNA accumulation by dexamethasone. J Biol Chem 262:460-464

53. Friedland J, Setton C, Silverstein E 1977 Angiotensin converting enzyme: induction by steroids in rabbit alveolar macrophages in culture. Science 197:64-65 